\title{
"In vitro efficacy of antiseptics to control Candida albicans present in the oral mucosa of apparently healthy patients"
}

\author{
${ }^{1}$ Nathália Neodine de Camargo $* ;{ }^{2}$ Marcela de Souza, \\ ${ }^{3}$ Miriam Magalhães Oliveira Levada ${ }^{4}$ Fernando Russo Costa do Bomfim, \\ ${ }^{5}$ Ana Laura Remédio Zeni Beretta. \\ Department of Clinical Microbiology, Block A, University Center Hermínio Ometto - Uniararas, Araras, SP, \\ Brazil - Avenue Dr. Maximiliano Baruto, 500 Jardim Universitário.
}

\begin{abstract}
Candida species are present in the flora of the skin and mucosa of man, and are of common occurrence in the oral cavity of healthy individuals, Candida albicans being the predominant species in the oral microbiota. Therefore, this study was to verify in vitro the effectiveness of oral antiseptics such as chlorhexidine digluconate 0.12\%, Cepacol ${ }^{\circledR}$, Flogoral ${ }^{\circledR}$ and Melaleuca $0.2 \%$ in the control of Candida albicans. We selected 30 strains of Candida albicans stored in specific culture medium. To the Müeller Hinton Agar - Biobrás (B was added sterile paper disks impregnated with the antiseptics studied, and then the samples were incubated at $37^{\circ} \mathrm{C}$ for 24 - 48 hours. Evidence of antifungal activity was the formation of inhibition zone around the paper disk, and evaluated by measuring the halos with a millimeter ruler. According to the results, it is clear that Chlorhexidine was startled on the other oral antiseptics because it has a broad spectrum of activity against various microorganisms. The Cepacol $®$ also stands out from others because it has a certain efficacy against the some microrganisms. The Flogoral ${ }^{\circledR}$ and Melaleuca is not observed as effective in the treatment of $C$. albicans.
\end{abstract}

Key-Words: Candida albicans; antiseptics; effectiveness; treatment.

\section{Introduction}

The oral cavity is colonized by various types of organisms that interact with each other and with the environment, forming an environmentally active community called oral biofilm. Candida species are present in the flora of the skin and mucosa of man, and are of common occurrence in the oral cavity of healthy individuals, but may also have the role of opportunistic pathogens and cause superficial and systemic infections $(9,13)$.

The finding of Candida in healthy individual, such as microbes, does not induce any disorder that can promote disease (13). Candida albicans (C. albicans) is the predominant species in the oral cavity, constituting 60 to $70 \%$ of total isolation, followed by C. tropicalis and C. glabrata (7).

Organical changes, regardless of its nature, usually favor the manifestation of the yeast fungus diseases to be considered an opportunist, especially when the spread is exacerbated by sharpening their virulence factors, and there is some irregularity functional human immune system (13). The disruption of the balance between Candida yeasts and microbial part of which provides the establishment of candidiasis, caused primarily by $C$. albicans in percentages ranging from 30 to $60 \%$, but other species such as $C$. tropicalis, $C$. pseudotropicalis, C. parapsilosis, C. stellatoidea, C. glabrata, C. guilhermondi, C. krusei, C. kefir and C. dubliniensis may also be related (2).

Over the past ten years, the incidence of serious infections caused by yeasts has increased and has occurred since the hospital to the community, in people with weak immune systems (21).

Recent studies have revealed the importance of the use of antimicrobial agents as an aid in the prevention and also in the treatment of oral candidosis (20).

The antimicrobial substances most commonly used form of oral rinses are: sodium fluoride, cetylpyridinium chloride, triclosan, thymol and chlorhexidine, among others (12).

Chlorhexidine is a cationic detergent, a bis-biguanide not toxic and is prepared in the form of various salts, including acetate, hidrocloride and chlorhexidine gluconate. It is considered an antiseptic broad spectrum that acts on Gram positive bacteria, Gram negative, fungi and yeasts (21). Chlorhexidine has a high affinity to the cell walls of microorganisms, the salivary mucopolysaccharides and hydroxyapatite. Its use in dentistry has antiplaque effect greater than other antimicrobial agents because of their strong adsorption capacity of the teeth and mucosal surfaces with subsequent release in the oral cavity at therapeutic levels (1).

Benzydamine hydrochloride or dimetilaminopropoxi-benzyl-indazol is a indazole composite and experimental data have demonstrated anti-inflammatory, antipyretic and analgesic activities (16). Its mechanism of action is common to those of inhibition of cyclo oxygenase enzyme in the prostaglandin biosynthetic cascade (22). 
Cetylpyridinium chloride is quaternary ammonium compound. This is an agent widely used in antiseptics, due to its antimicrobial properties. The mechanism of action is related to increased permeability of the cell wall, which favors the analysis, decreases the cellular metabolism, and the ability of bacteria to adhere to the tooth surface (19).

Dental products containing natural substances have good prospects in the market due to popular acceptance of herbal medicine, and could be introduced since that widely supported by laboratory studies and clinical purposes (19).

More recent studies have reported that Melaleuca also has an antiseptic effect, which promotes the elimination of microorganisms. The Melaleuca alternifolia, commonly known as Tea Tree, became known in the occident from the expedition of Captain James Cook who in 1770 landed in Botany Bay in Australia, where he noticed that the Aborigines were using a tea leaves from one tree with medicinal properties (18). These are shrubs of the family Myrtacea), can reach 7 feet tall, has thin skin and long pointed leaves that emit a strong aroma $(17,6)$.

Chemically, essential oil from leaves of Melaleuca alternifolia is composed primarily of terpinen-4ol, the most responsible for its medicinal properties, especially antifungal and antibacterial properties. The oil of Melaleuca does not stain, has good tissue penetration properties and is compatible with soaps, and is considered a powerful solvent (14).

According to the study by the Australian Tea Tree Oil Research Institute and University of Queensland (Sydney), the tea tree oil acts as an antimicrobial through (1) disruption of the cell membrane, (2) the formation of bubbles on the surface of extracellular membrane and leakage of cytoplasm and (3) inhibition of the process of cellular respiration (14).

In a study of the research department of the National College of Chiropractic, USA, it was found that tea tree oil acts as an antiseptic by (1) a direct action on the microorganisms and (2) a process of activation of white cells in process the body's defense (14).

According to the foregoing, it is intended to investigate the efficacy of antiseptics used in infections of the oral cavity, such as chlorhexidine digluconate $0.12 \%$, the Cepacol ${ }^{\circledR}$ (Cetylpyridinium chloride), the Flogoral ${ }^{\circledR}$ (Benzydamine) and Melaleuca $0.2 \%$ in controlling the growth of $C$. albicans, comparing the efficacy of products.

\section{Material And Methods}

This study was conducted after approval by the Research and Scientific Merit of the University Center Hermínio Ometto - UNIARARAS, protocol number 100/2008 following the rules of the resolution 196/96 of CONEP.

All strains of C. albicans in this study were isolated from samples of the oral cavity of apparently healthy individuals, and were stored in the Laboratory of Clinical Microbiology of the University Center Hermínio Ometto - UNIARARAS. The antiseptic used in this study were: chlorhexidine digluconate $0.12 \%$, Cepacol ${ }^{\circledR}$, Flogoral ${ }^{\circledR}$ and Melaleuca $0.2 \%$.

We selected 30 strains $C$. albicans were suspended in specific culture medium. The suspension was prepared by comparing the turbidity with tube 4 of the Range Mac Farland. Sterile swab was immersed in the inoculum and transferred into Müeller Hinton Agar - Biobrás ®. Discs sterile filter paper were impregnated with the antiseptics studied, and the samples incubated at $37^{\circ} \mathrm{C}$ for $24-48$ hours, in duplicate. After incubation, we observed the formation of inhibition zones around the discs. The diameters of the halos were measured with the assistance of a millimeter ruler and subjected to analysis.

\section{Results}

The results of the in vitro test have been through the measures of the inhibition zones formed around the paper disks, as shown in Figure 1.

The chlorhexidine showed antifungal activity against the strains $C$. albicans superior to other oral antiseptics. The Cepacol ${ }^{\circledR}$ showed effectiveness against some strains of C. albicans. The Flogoral ${ }^{\circledR}$ and Melaleuca did not show to be effective. The results were subjected to statistical analysis. In our study, the chlorhexidine digluconate $0.12 \%$, showed satisfactory results, with halos ranging from $4-15 \mathrm{~mm}$, followed by Cepacol $\AA$, with halos from $1-9 \mathrm{~mm}$. The Flogoral ${ }^{\circledR}$ and Melaleuca $0.2 \%$ did not provide satisfactory results, with halos of measurement ranging from $0-2 \mathrm{~mm}$ and $0-3 \mathrm{~mm}$, respectively.

\section{Discussion}

Currently, several antifungals have been indicated in the treatment of oral candidiasis. But, according to Farias et al. (2003) (5), until now there is no ideal antifungal therapy, agents or employees are not $100 \%$ effective or have side effects by patients (toxicity, bad taste, etc.). 
According to Candido et al. (1996) (3), the application of oral antiseptics deserves to be considered, at least as a preventive measure, as well as an alternative or complement in therapy.

Several studies have shown that chlorhexidine has antimicrobial activity. Menezes et al. (2008) (11) demonstrated that $S$. aureus, E. faecalis and $C$. albicans were highly susceptible to chlorhexidine. In the study by Farias et al. (2003) (5), the chlorhexidine demonstrated an antifungal effect against the strains of $C$. albicans than the solution of nystatin.

Marinho and Araújo (2007) (10) describe their studies on the sensitivity of Lactobacillus front of oral antiseptics on the market, and the best results were obtained by the following antiseptics, in its order: Periogard (® (active ingredient: chlorhexidine $0.12 \%$ ); Malvona ${ }^{\circledR}$ (active ingredient: sodium borate); Wash ${ }^{\circledR}$ (active ingredient: benzalkonium chloride); Malvatricin ${ }^{\circledR}$ (active ingredient: tirotricina $0.25 \%$ ). The Flogoral ${ }^{\circledR}$ (active ingredient: benzidamida hydrochloride $0.15 \%$ ) showed to be effective in reducing Lactobacillus saliva.

In a study reported by Drumond et al. (2004) (4), was evaluated the efficacy of several antiseptics in reducing $C$. albicans in saliva viewing this in vitro its activity. Were selected 50 samples of saliva of individuals with age ranging from 19 to 54 years and apparently healthy who presented to C. albicans. The oral antiseptics used were: Kolynos $\AA$, Oral - B $₫$, Cepacol $\AA$, Periogard $\AA$, Flogoral $\AA$, Fluordent ${ }^{\circledR}$, Plax $₫$ Wash $\AA$, Listerine ${ }_{\circledR}$ and Malvatricin ${ }^{\circledR}$. The results showed that the products and Listerine ${ }^{\circledR}$ Flogoral ${ }^{\circledR}$ showed no antimicrobial activity. The other products tested showed the ability to reduce yeast below the Malvatricin ${ }^{\circledR}$ and Periogard $\AA$, indicating that the Periogard $₫$ and Malvatricin ${ }^{\circledR}$ are the ones with great potential, and that the products Kolynos ${ }^{\circledR}$, Oral - B ${ }^{\circledR}$, Cepacol ${ }^{\circledR}$, Fluordent ${ }^{\circledR}$, Wash ${ }^{\circledR}$ and Plax ${ }^{\circledR}$ are also able to act as antimicrobial, but on a smaller scale.

Farias et al. (2003) (5) consider the fact that the in vitro effects can not be directly compared with effects in vivo, because the results indicate that yeasts of different Candida species could be inhibited by the application of commercial products Periogard ${ }^{\circledR}$ and propolis with therapeutic purpose and/or preventive against oral candidiasis.

According to the results obtained in our study, and related them with other studies, it is clear that the Chlorhexidine stands on the other oral antiseptics. But studies show that it has a broad spectrum of action also against several other pathogens.

The Cepacol $®$, used in other studies with different trade names, also stands out from others because it has some efficacy against some microorganisms. Flogoral @ and Melaleuca do not had effectiveness on control of $C$. albicans in our study, nor in control of other microorganisms present in saliva, as reported by other studies.

But it is very important to remember that, despite the demonstrated effectiveness of chlorhexidine digluconate $0.12 \%$, one must be mindful of the adverse reactions caused by it. Studies show that prolonged use as a solution to mouthwashes causes stains in the enamel of the tooth and the tongue, altered taste, burning sensation in the mouth, unpleasant taste and change the taste of food after its use (15). Therefore, one should carefully observe the recommendations for the use of this type of solution.

This study may help to understand that the use of chemicals and herbals oral antiseptics can contribute to the improvement and reduce the incidence of oral candidiasis, as well as assist in controlling $C$. albicans involved in biofilm formation.

Allergic reactions to chlorhexidine are well known since 1962, when the literature has reported a case of contact sensitivity. Today, chlorhexidine is known for the risks of contact dermatitis, including during sex, after prolonged use. Other reactions include urticaria, photosensitivity and occupational asthma (8).

Thus, considering the characteristic of natural product effectiveness, palatability and safety, this in vitro study proposes an evaluation of the efficacy of chemicals and natural antiseptics, with the aim of proposing an alternative therapy to clinical dentistry.

PIBIC

\section{Acknowledgments}

\section{References}

[1]. BEVIlaCQUA, I. M.; HABITANTE, S. M.; CRUZ, C. W. (2004). A Clorexidina como Alternativa no Tratamento de Infecções Endodônticas. Rev. biociên. 10 (3), 139-145.

[2]. BUENO, M. E.; FEIJO, A. M.; COIMBRA, H. S.; NASCENTE, P. S. (2005). Pesquisa de Candida spp na microbiota oral de crianças. Congresso de Iniciação Cientifica UFPel, Pelotas, RS.

[3]. CANDIDO, R. C.; AZEVEDO, R. V.; ITO, I. Y. (1996). Determinação da Concentração Inibitória Mínima de Cepacol, Malvona e Periogard, Ante a Cândida albicans Isoladas da Cavidade Bucal. Ver. Odontol. UNESP. 25 (1), 79-84.

[4]. DRUMOND, M. R. S.; CASTRO, R. D.; ALMEIDA, R. V. D.; PEREIRA, M. S. V.; PADILHA, W. W. N. (2004). Estudo Comparativo in vitro da Atividade Antibacteriana de Produtos Fitoterápicos Sobre Bactérias Cariogênicas. Pesq. Bras. Odontoped. Clin. Integr. 4 (1), 33-38.

[5]. FARIAS, N. C.; BUFFON, M. M.; CINI, R. (2003). Avaliação in vitro da Ação Antifúngica do Digluconato de Clorhexidina e Nistatina no Controle do Crescimento de Candida albicans. Visão Acadêmica. 4 (2), 83-88. 
[6]. HAMMER, K.A.; CARSON, C. F. ; RILEY, T. V. ; NIELSEN, J. B. (2006). A review of toxicity of Melaleuca alternifolia (tea tree) oil. Food and Chemical Toxicology. 44 (5), 616-625.

[7]. JORGE, A. O. C.; KOGA-ITO, C. Y.; GONÇALVES, C. R.; FANTINATO, V.; UNTERKIRCHER, C. S. (1997). Presença de Leveduras do Gênero Candida na saliva de Pacientes com Diferentes Fatores Predisponentes e de indivíduos Controle. Rev. Odontol. Univ. 11 (4), 279-285.

[8]. KRAUTHEIM, A.B.; JERMANN, T. H.; BIRCHER, A. J. (2004). Chlorhexidine anaphylaxis: case report and review of the literature. Contact Dermatitis. 50 (3), 113-116.

[9]. KUMANOTO, C. A. (2002). Candida Biofilms. Curr, Opin, Microbiol. 5 (6), 608-611.

[10]. MARINHO, B. V. S., ARAÚJO, A. C. S. (2007). Uso dos Enxaguatórios Bucais Sobre a Gengivite e Biofilme Dental. International Journal of Dentistry. 6 (4), 124-131.

[11]. MENEZES, M. M.; OLIVEIRA, L. D.; KOGA-ITO, C. Y.; JORGE, A. O. C.; VALERA, M. C. (2008). Concentração Fungicida Mínima das Soluções de Clorexidina e Hipoclorito de Sódio Sobre Candida albicans. Cienc. Odontol. Bras. 11 (2), 23-28.

[12]. MONFRIN, R. C. P.; RIBEIRO, M. C. (2000). Avaliação in vitro de anti-sépticos bucais sobre a microbiota da saliva. R. Assoc. Paul. Cir. Dent. 54 (1), 401-407.

[13]. RIBEIRO, E. L.; GUIMARÃES, R. I.; INÁCIO, M. C. C.; FERREIRA, W. M.; CARDOSO, C. G.; DIAS, S. M. S.; NAVES, P. L. F. (2004). Aspectos das Leveduras de Candida Vinculadas às Infecções Nosocomiais. Rev. NewsLab. 64, 106-107.

[14]. SANTOS, L. P. (2004). Ação antimicrobiana do Fitoterápico Melaleuca alternifolia (Myrtaceae). Araras, SP, Brasil, 23p. (Monografia Centro Universitário Hermínio Ometto).

[15]. SANTOS, P. S.; MARINHO, N. V.; NETTO, C. A. (2008). Avaliação Comparativa da Atividade Antimicrobiana de Enxaguatórios à Base de Clorexidina e Própolis Tipificada: Métodos de Coleta de Saliva e Reações Adversas. I Jornada de Iniciação Científica e Tecnológica UNIBAN, p. 1-3.

[16]. SCHVARTSMAN, C.; SCHAVARTSMAN, S. (1986). Intoxicação por Benzidamina Conseqüente à Ingestão de Colutório Antiinflamatório. Pediat. 8, 107-109.

[17]. SIMÕES, R. P.; GROPPO, F. C.; SARTORATO, A.; FIOL, F. S.; FILHOS, T. R. M.; RAMACCIATO, J. C.; RODRIGUES, M V. N. (2002). Efeito do óleo de Melaleuca alternifolia sobre a infecção estafilocócica. Revista Lecta. 20(2), 143-152,

[18]. TESKE, M.; TRENTINI, A.M.M. (1994). Herbarium Compêndio de Fitoterapia. Herbarium laboratório botânico Ltda., Curitiba, PR.

[19]. TORRES, C. R. G.; KUBO, G. H.; ANIDO, A. A.; RODRIGUES, J. R. (2000). Agentes antimicrobianos e seu potencial de uso na Odontologia. Pós-Grad. Rev. Fac. Odontol. São José dos Campos. 3 (2), 43, 45, 46.

[20]. TORTORA, G. J.; FUNKE, B. R.; CASE, C. L. (2000). Microbiologia. Artmed, Porto Alegre, RS.

[21]. VINHOLIS, A. H.; GONÇALVEZ, P. C.; MARCANTONIO, R. A. C.; MARCANTONIO JÚNIOR, E. (1996). Mecanismo de Ação da Clorexidina. Revista Periodontia. 5 (3), 281- 283.

[22]. Available at:http://www.pdamed.com.br/diciomed/pdamed_0001_03291.php. Accessed September 15, 2009.

\section{FIGURE}

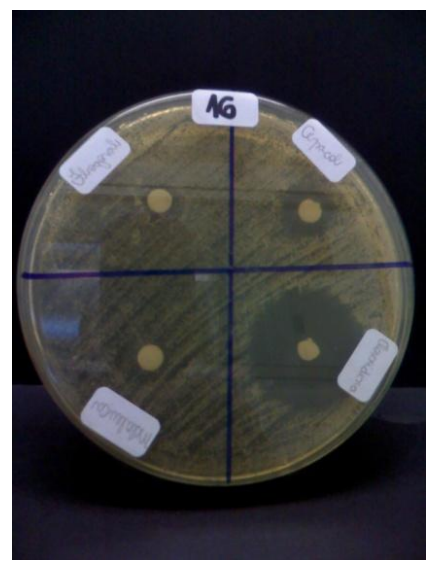

Fig. 1: Inhibition halos formed around the paper disks impregnated with the antiseptics studied

TABLE

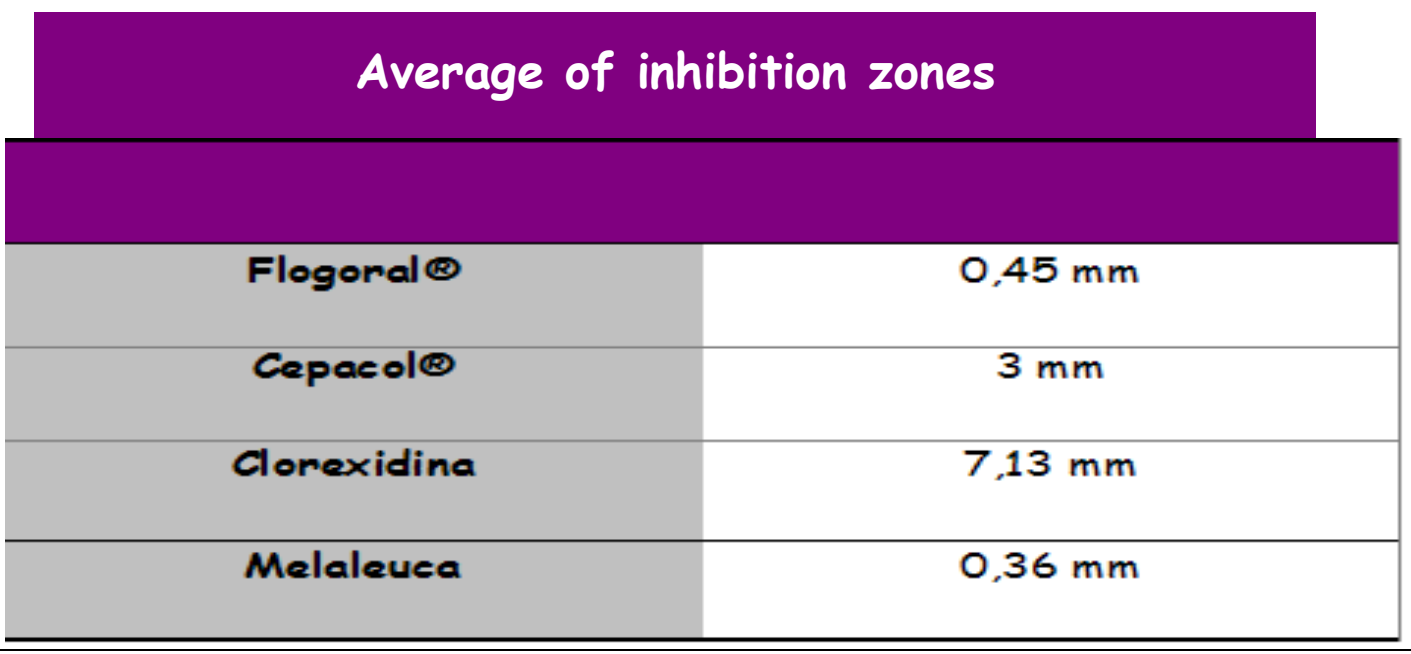


Table 1: Table of the average of inhibition zones

\section{GRAPHICS}

\section{Strains Inhibited}

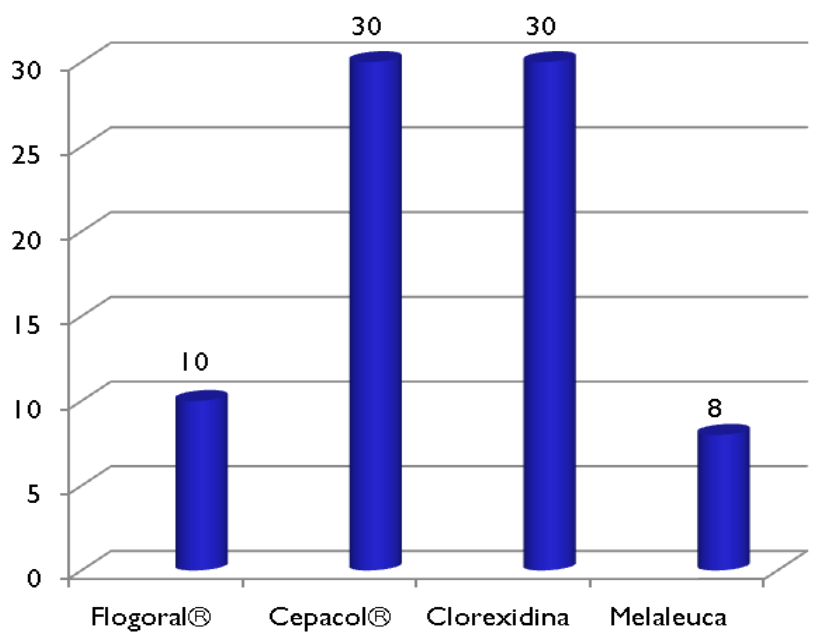

Graphic 1: Graph of all strains inhibited by antiseptics

\section{Differences between the means}

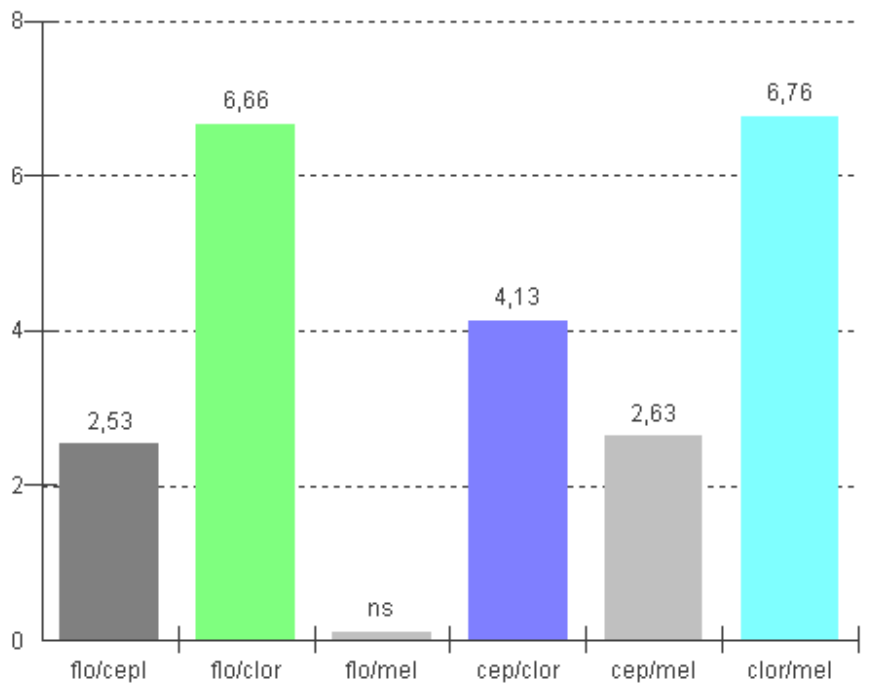

Graphic 2: Graph of differences between the means of antiseptics 